\title{
The Use Of A Tutorial Video-Aided Learning Module On Soil Mechanical Practicum
}

\author{
Suhairiani $^{1}$, Nahesson. H. Panjaitan ${ }^{2}$, Enny Keristiana Sinaga ${ }^{3}$ \\ ${ }^{1,2,3}$ Universitas Negeri Medan, Medan, Indonesia \\ suhairiani@unimed.ac.id
}

\begin{abstract}
This study aims to improve the mastery of the material in the soil mechanics practicum course by using a learning module that is equipped with a video tutorial on S1 Civil Engineering students. it is a Research and Development learning media based on print and audio visual media in the form of modules and videos aided by the adobe premiere pro cc application that uses $4 \mathrm{D}$ research procedures that have been modified into 3 stages namely, (1) the defining stage, analyzing the soil mechanics practicum material (2) design phase, module making and video using adobe premiere pro cc (3) application development stage, product making in the form of teaching modules, complete with video tutorials. instruments used, validation sheets for media and material experts, media evaluation questionnaires by lecturers and student questionnaire responses given to 30 students. The results of the research validation show that the learning module that is equipped with a video tutorial that is packaged in the form of a book and a CD has good criteria and the results of a questionnaire analysis of student interest in learning are positive, meaning that it can improve the effective learning process, especially of testing procedures and data analysis.
\end{abstract}

Keywords: Adobe Premiere Pro cc, Modules, Soil Mechanical Practicum, Video Tutorials

\section{Introduction}

Practical Soil Mechanics courses are required subjects for students in the S1 Civil Engineering, D3 Civil Engineering or S1 Building Engineering Education courses. The Soil Mechanics course is very important because students are expected to not only understand and master the theory obtained in the Soil Mechanics course but can also practice and apply the theory using practicum tools used to collect data so that at the end of the practicum students can interpret the data and collect it into a practicum report correctly.

In the learning process delivery of a material to achieve the learning outcomes is very important with the material and skills that must be mastered students, student learning requires supporting tools such as tools / media / learning resources. "Learning media is a tool that serves to convey learning messages" [1]. To convey learning messages from teachers to students, teachers usually use teaching aids in the form of images, models, or other tools that can provide concrete experiences, motivation to learn, and enhance power absorbency and learning retention [2]. The use of teaching aids or learning media is an inseparable part and is an integration of the 
learning methods used. Learning aids are one of the dynamic elements in learning. The position of aids has an important role because it can help the learning process of students. The use of assistive device is for abstract learning materials can be concrete and make an unattractive learning atmosphere interesting. Many learning aids or media are created for independent learning nowadays, but to find a choice or a solution for tools that are really good so that the learning process becomes effective and interesting and fun is a problem that needs to be sought a solution.

Learning modules are instructional materials that are arranged systematically and attractively covering the contents of the material, methods and evaluations that can be used independently to achieve the expected competencies [3].The module developed must have the characteristics needed as a module in order to be able to produce modules that are able to increase the motivation to use it. The five characteristics of a module are self-instruction, selfcontained, stand alone, adaptive, and user-friendly. Currently students only use standard practicum modules and theory books that are relevant to the material. And from the results of the use of standard modules only $11.27 \%$ of students received an A grade, $33.80 \%$ of students received a $\mathrm{B}$ grade, $49.30 \%$ of students received a $\mathrm{C}$ grade and $5.63 \%$ of students received an $\mathrm{E}$ score, from the percentage obtained can be seen still finding a declining final value in learning outcomes in the Soil Mechanics Practicum course.

The final grade indicator is not good because, firstly, students still find it difficult to understand the material when carrying out the test which results in many errors found in testing, secondly, there are still many errors found in interpreting the results of the test data. From the two indicators, at the final examination of practicum grades in the Soil Mechanics course still found $\mathrm{C}$ and $\mathrm{E}$.

Educational Industry Revolution 4.0 is a general term used by educational theorists to describe various ways of integrating technology. The number of technological applications is one of them in making videos. From the results of the above learning values in this study the author tries to do development research by displaying a learning module that is equipped with a video tutorial. Making this video using the help of a computer program that is using the Adobe Premiere Pro cc program.

Adobe Premiere Pro cc is a non-linear (NLE) based video editing program from Adobe Systems. That is one software product from Adobe Creative Suite.

Adobe Premiere Pro cc has about 45 video effects and 12 audio effects, which are able to change the display pattern and animate video and audio clips. Adobe Premiere Pro has important features, including Monitor Capture (video recorder) Monitor, Trim (clip cutting tool) Monitor, and Titler (Maker of title text) Monitor. In Adobe Premiere Pro cc video effects, there are Keyframes like those in Adobe After Effects (how to animate them is almost the same). In Titler, you can make the title text and change the properties of the text such as changing the shape of the letters, giving and changing colors, giving contours, outlines, making motion animations or moving text (roll and / or crawl), can also be used to give shapes / shapes so that the appearance of the title / text of the video looks more attractive. The last stage is export / output / save the project in the form of video and distributed to various media that can display video formats [4].

The selection of this program is intended to produce good quality video results, because the results of this development research are expected to have an increased impact on learning outcomes. So as to motivate students to be more creative, effective and efficient, and can reduce student boredom in the learning process, and as a basic capital skills (skills) in the work of land inspection and investigation in the world of Civil Engineering construction. 


\section{Research Methods}

This type of research is research and development. Research and development methods are research methods used to produce certain products and test the effectiveness of these products [5]. The product developed is a learning module that is assisted by video tutorials on soil mechanics practicums for S1 Civil Engineering students in 2019/2020 Academic Year.

This development model is modified from the 4D learning device model developed by Thiagarajan, Dorothy S. Semmel, and Melvyn I Semmel which consists of 4 stages namely define, design, develop, and disseminate [6]. But in this study only carried out three stages, namely the definition, design and development. In this study only carried out until the development stage due to time constraints, there are also steps in the design stage to produce a learning model can be seen in Figure 1 below.

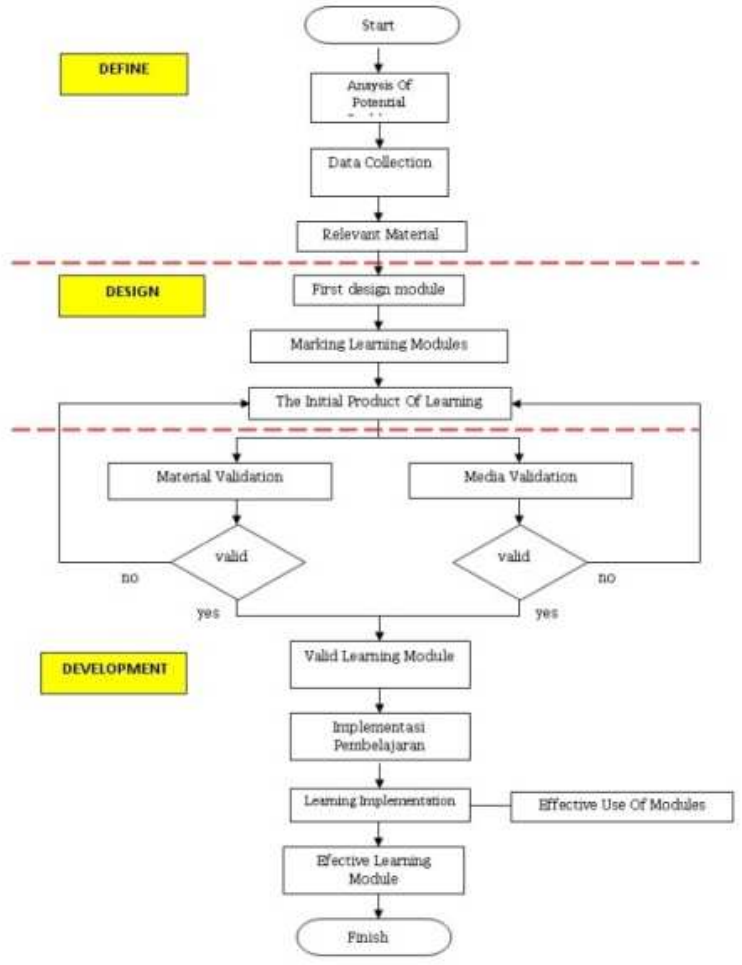

Fig 1. Flowchart of Research Methods

There are 3 (three) data obtained in this study, namely (1) Media Validity data obtained from the material expert validator and the media expert validator, (2) practicality data obtained from the practicality test of the module which was tested with 6 samples of students who took eyes soil mechanics practice lectures, and (3) effectiveness data obtained from valid, practical and effective module effectiveness tests, which were tested with 26 Civil Engineering undergraduate students taking Civil Engineering practicum courses in 2019/2020.

In this study, the data analysis technique used is quantitative descriptive analysis. In this study the data for the feasibility analysis obtained from a validation questionnaire by media 
experts, learning material experts. The results of the assessment by experts on the validation sheet are classified into 5 categories of choices with a rating scale range of 5 scores, scores 2 , scores 3 , scores 4 , and scores 5 . Data analysis techniques with 5 categories are chosen by grouping data based on product qualifications will be assessed. The average score obtained is then entered into qualitative categories as contained in Table 1 that was adapted from [7].

Table 1. Criteria for Quantitative Data Conversion to Qualitative Data

\begin{tabular}{cc}
\hline Score Range & Category \\
\hline$X>\overline{X_{i}}+1,8 s b i$ & Very Good \\
\hline$\overline{X_{i}}+0,6 s b i<X \leq \overline{X_{i}}+1,8 s b i$ & Good \\
\hline$\overline{X_{i}}-0,6 s b i<X \leq \overline{X_{i}}+0,6 s b i$ & Good Enough \\
\hline$\overline{X_{i}}-1,8 s b i<X \leq \overline{X_{i}}-0,6 s b i$ & Poorly \\
\hline$X \leq \overline{X_{i}}-1,8 s b i$ & Very Poor \\
\hline
\end{tabular}

With; $\mathrm{x}=$ average score; $\overline{\mathrm{X}_{\mathrm{i}}}=$ ideal score average $(1 / 2 \max$ score + min score $)$; sbi $=$ standard deviation idea (1/6 max score + min score). In this study learning media is said to be valid if it meets the minimum good qualitative criteria. Learning media is said to be practical if the teacher's assessment and student's assessment of learning are in a practical category, The questionnaire of media practicality is described by the technique of frequency data analysis using the formula [7].

$$
\bar{X}=\frac{\sum_{i}^{n} x_{i}}{n}
$$

With; $\mathrm{x}=$ average score; $\mathrm{n}=$ many statement items; dan $\mathrm{xi}=$ score on the question to $-\mathrm{i}$ The practicality category using the Likert scale does not allow the statement of neutral items [8]. So there are only two statements on the Likert scale, positive item statements and negative item statements. And grouped as in Table 2 below.

Table 2. Response Attitude Categories

\begin{tabular}{lc}
\hline Response Attitude Categories & Score Range \\
\hline Very positive attitude & Kuartil $3 \leq X$ \\
& $\leq$ skor maksimal \\
\hline Positive attitude & Median $\leq X<$ kuartil 3 \\
\hline Negative attitude & Kuartil $1 \leq X<$ median \\
\hline Very negative attitude & Score Minimal $\leq X$ \\
& $<$ Kuartil 1 \\
\hline
\end{tabular}

Where:

Minimum : The minimum score obtained by each respondent multiplied by the number of respondents

Median : The sum of the maximum total scores with a minimum total score divided by two

Quartile I : The sum total of the minimum score with a median divided by two

Quartile 3 : Maximum score sum results with a median divided by two Maximum : The maximum score obtained by each respondent multiplied by the number of
respondents 


\section{Results And Discussion}

Development Procedure

3.1 Define Stage

Activities at this stage are carried out to establish and define development requirements. In general, in this definition activities are carried out to identify problems and data collection processes. From the results of the identification of the problems carried out using the method of observation and interviews to the team of lecturers supporting the soil mechanics practicum course and obtained data (a) the low understanding of students in the soil mechanics testing material, (b) there are still many errors found in testing, (c) there are still many errors found in interpreting the test data, (d) there is no module used in learning, only fixated on the practicum handbook. And the process of activities carried out at the time of data collection is conducting observations related to learning data such as syllabus/rps, and looking for material sources that will be used for research as well as for making modules and videos from several references.

\subsection{Design Stage}

Making the initial product or product design. There are also steps in the design stage to produce learning are designing the initial design of the module, collecting material to be made on the module and making the learning module, which then the results of making the module are made into a video. The appearance of the module and video as shown in Figures 2 and 3 below.



Fig 2. Display of Learning Modules



Fig 3. Display Learning Videos

\subsection{Development Stage}

Module Validation and Learning Videos by Material Experts. The material validator is conducted by 2 (two) material experts who have Geotechnical expertise from 2 universities namely Medan State University, and Muhammadiyah University, North Sumatra. Overall the validator gave a score of $83.53 \%$ for the use of learning modules and $90 \%$ for video tutorials on soil mechanics practicum courses. It can be concluded that the learning module developed in terms of the material is categorized as "very good (SB)". And aspects of the assessment of learning modules and the use of video tutorials can be seen from Figure 4 and 5 below. 


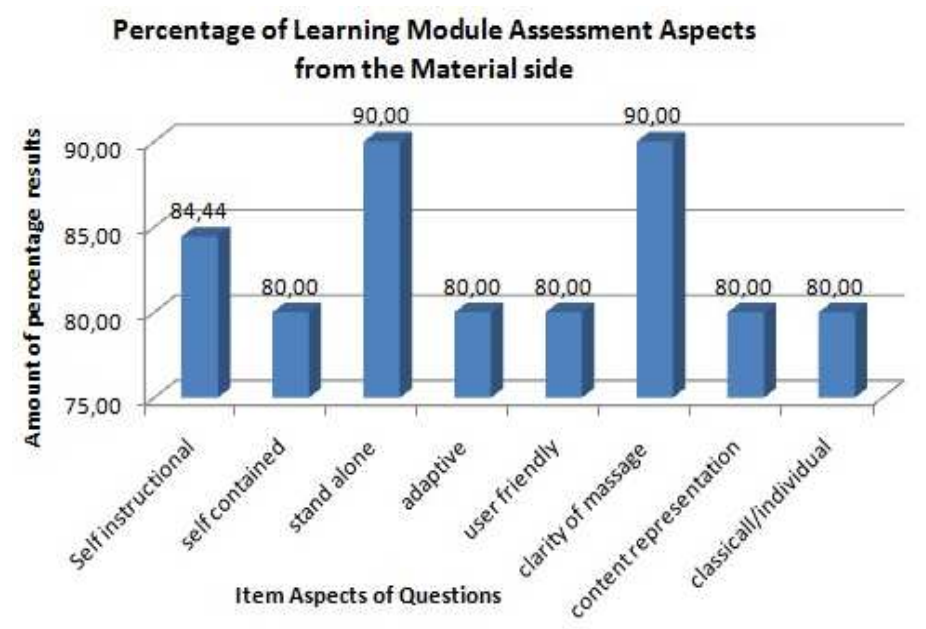

Fig 4. Percentage Of Learning Module Assessment Aspect From The Material Side

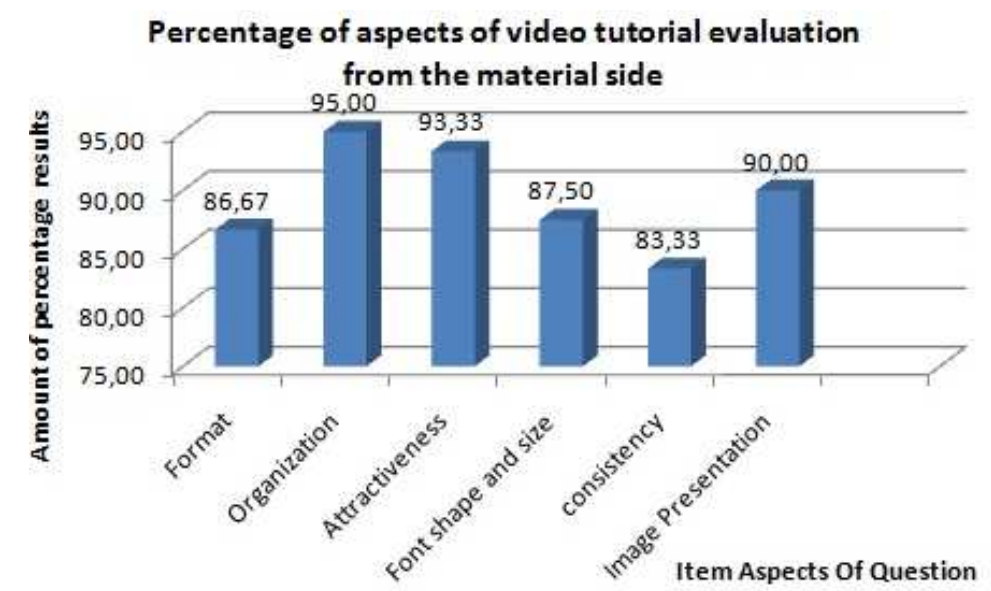

Fig 5. Percentage Of Aspects Of Video Tutorial Evaluation From The Material Side

\section{Module Validation and Learning Videos by Media Experts}

For media validators, 2 (two) media experts have media expertise from 2 universities, Medan State University and North Sumatra Muhammadiyah University. Overall the validator gave a score of $91.82 \%$ for the use of learning modules and $92.5 \%$ for video tutorials on soil mechanics practicum courses. It can be concluded that the learning modules developed from the media side are categorized as "good (B)". And aspects of the assessment of learning modules and the use of video tutorials can be seen from Figure 6 and 7 below. 


\section{Percentage of Learning Module Assessment Aspects from the media side}



Fig 5. Percentage Of Learning Module Assessment Aspect From The Media Side

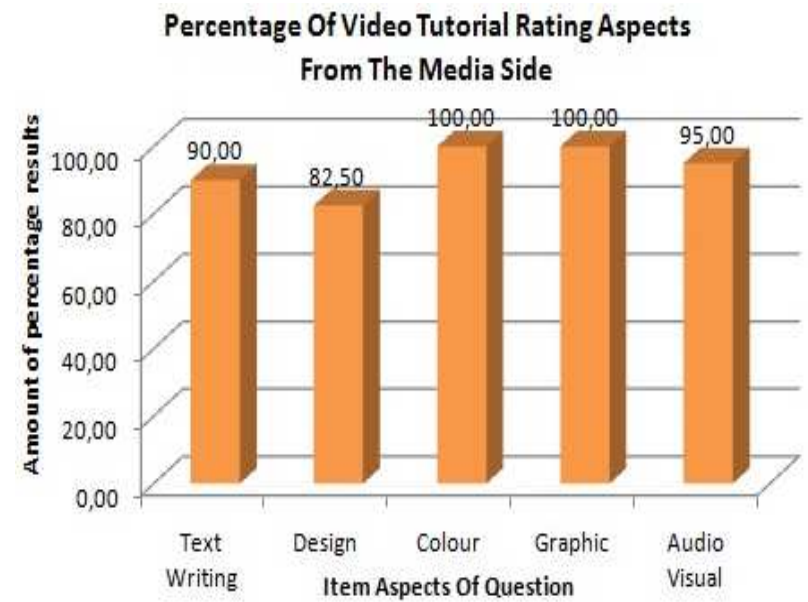

Fig 6. Percentage Of Video Tutorial Rating Aspect From The Media Side

\section{Revision Of Model I}

The learning model that has been developed and has been corrected by media experts and material experts, there will be inputs for improving the product / learning model.

\section{Practical Test}

Practical Test is limited to learning in the classroom according to the real situation encountered. In this study, a limited trial was conducted on 6 students. In accordance with the formulation contained in Table 2 and aspects of material assessment and media display by students on a limited product trial can be seen in Table 3 and table 4 below. 
Table 3. Aspects of Material Evaluation by Student On Practical Tests

\begin{tabular}{|c|c|c|c|c|c|c|c|}
\hline \multirow{2}{*}{ NO } & \multirow{2}{*}{ Rating Item } & \multicolumn{6}{|c|}{ Students } \\
\hline & & 1 & 2 & 3 & 4 & 5 & 6 \\
\hline 1 & Easy to understand the material & 5 & 5 & 5 & 5 & 4 & 5 \\
\hline 2 & Language is easy to understand & 5 & 4 & 5 & 4 & 5 & 5 \\
\hline 3 & Font size of the font is easy to read & 5 & 5 & 3 & 5 & 4 & 5 \\
\hline 4 & Image clarity & 5 & 5 & 5 & 4 & 5 & 5 \\
\hline 5 & Match between material and module with clarity of illustration & 4 & 5 & 5 & 4 & 5 & 5 \\
\hline 6 & Exercise & 5 & 4 & 5 & 4 & 4 & 5 \\
\hline 7 & Answer key & 5 & 5 & 5 & 5 & 4 & 5 \\
\hline 8 & Information increases student knowledge & 5 & 5 & 3 & 4 & 5 & 5 \\
\hline 9 & The understanding process is helped by modules and videos & 4 & 4 & 4 & 5 & 5 & 4 \\
\hline 10 & References increase student knowledge & 5 & 5 & 4 & 5 & 5 & 5 \\
\hline 11 & Modules and videos can focus attention & 5 & 4 & 5 & 4 & 5 & 5 \\
\hline 12 & Practicality of Modules & 5 & 5 & 3 & 5 & 3 & 5 \\
\hline \multirow[t]{3}{*}{13} & Enthusiastic and motivated learning using modules & 5 & 5 & 4 & 5 & 4 & 5 \\
\hline & Total Score & 63 & 61 & 56 & 59 & 58 & 64 \\
\hline & Total Number of Scores & & \multicolumn{5}{|c|}{361} \\
\hline
\end{tabular}

And if the total value of the total score entered into Table 2, the values obtained as in Table 4 below.

Table 4. Results of Response Attitudes Categories

\begin{tabular}{lc}
\hline Response Attitude Category & Score Category \\
\hline very positive attitude & $312-390$ \\
\hline positive attitude & $234-312$ \\
\hline negative attitude & $156-234$ \\
\hline very negative attitude & $78-156$ \\
\hline
\end{tabular}

Overall, it can be concluded that students who conduct practical tests state that the material in the learning module that is developed is included in the aspect of the category of very positive attitude.

\section{Revision Of Model II}

The revision of the model at this stage is no longer based on the results of validation or expert input. but the revised model, based on the results at the time of the practical test. Overall, from the aspect of learning and media aspects the results of limited trials conducted by 6 students showed that the material on the learning media developed included the aspects of the category of positive response attitudes and the media was appropriate to be used for $26 \mathrm{~S} 1$ Civil Engineering students who took the soil mechanics practicum.

\section{Effective Test}

Effectiveness testing on soil mechanics practicum courses was conducted on 26 students. Effectiveness is obtained from the value of learning outcomes data from test results, namely pre-test before treatment and post-test after treatment. Learning outcomes here are included to find out the improvement in learning outcomes after the pretest and posttest. This test aims to 
determine whether a certain value (which is given as a comparison). Here are the experimental value data as in Table 5 below.

Table 5. List of Pre-Test and Post-Test Scores

\begin{tabular}{ccc}
\hline \multirow{2}{*}{ Score } & \multicolumn{2}{c}{ Total Students } \\
\cline { 2 - 3 } & Pretest & Postest \\
\hline 40 & 3 & 0 \\
\hline 50 & 9 & 0 \\
\hline 60 & 9 & 0 \\
\hline 70 & 4 & 8 \\
\hline 80 & 1 & 5 \\
\hline 90 & 0 & 2 \\
\hline 100 & 0 & 26 \\
\hline Total & 26 &
\end{tabular}

From the results of Table 5 above, the average Pre-Test and Post-Test scores are:

a. Average Pre Test scores

$$
\overline{X_{o}}=\frac{\sum x_{i}}{n}=\frac{1470}{26}=56,54
$$

b. Average Post Test scores

$$
\overline{X_{o}}=\frac{\sum x_{i}}{n}=\frac{2060}{26}=79,23
$$

A student has the ability to understand a material concept that is taught, if the criteria are of good value or have an interval range of 60-80 [7].

In this study a video tutorial assisted learning module to improve the ability to understand the concept of material in the soil mechanics practicum 2019/2020 Academic Year is considered effective if the percentage of posttest is greater than the percentage of pretest and good classification.

To get these criteria, the interpretation of the learning completeness data of students must be calculated first, where from the results of the data in Table 5 above obtained the percentage of completeness for Pre-Test and Post-Test is learning completeness data obtained

a. Percentage of completeness pretest

$$
(\text { pretest })=\frac{14}{26} \times 100 \%=53,84 \%
$$

b. Percentage of completeness posttest

$$
(\text { posteste })=\frac{23}{25} \times 100 \%=88,47 \%
$$

Based on the analysis it was found that the percentage of posttest was greater than the percentage of pretest $(88.47>53.84 \%)$ and was in the Good criteria. So it can be concluded that the video tutorial assisted learning module is declared effective for use in learning the soil mechanics practicum course.

\section{Conclusion}

Based on the results of research and discussion, it can be concluded that: The first design of learning modules for soil mechanics practicum courses with video tutorial assistance developed through 3 stages, namely: (1) Definition (2) Design of display design and (3) development. Secondly the quality of the learning modules for soil mechanics practicum 
with video tutorials developed, which are divided into 3 elements: material, media, and student experience using modules and videos. The third assessment of the material on the learning media as a whole validator of the material gave a score of $83.53 \%$ for the use of learning modules and $90 \%$ for video tutorials on soil mechanics practicum and entry into excellent categories (SB), as well as the evaluation of material on video tutorials, in the overall validator gave a score of $91.82 \%$ for the use of learning modules and $92.5 \%$ for video tutorials on soil mechanics practicum courses. and enter the category of "good (B)". And the fourth the students' responses to their experiences using the learning module of the soil mechanics practical course video tutorial seen from two aspects, namely: limited trials (small groups) and effectiveness trials (large groups), Overall, that students who conduct limited trials and the effectiveness test states that the material and media in the learning module of soil mechanics practicum with video tutorial developed are included in the category of positive response attitude categories, and can be used as an alternative media to improve mastery in the learning of soil mechanics practice courses because it is good from in terms of material and media design.

\section{Acknowledgements}

Thanks to the Department of Building Engineering, at the Medan State University for competitiveness research at the faculty level (KDBK) in 2019.

\section{References}

[1] Arsyad, A. Media Pembelajaran, Edisi 1. Jakarta: PT. Raja Grafindo Persada (2002).

[2] Arief S, S. d. Media Pendidikan, Pengertian, Pengembangan dan Pemamfataannya. Jakarta: Rajawali Press (2009).

[3] Anwar, I. Pengembangan Bahan Ajar Bahan Kuliah Online. Bandung: Direktori UPI

[4] Wikipedia Adobe Premiere Pro. (2019 йил 25-9). https://id.wikipedia.org/ wiki/Adobe Premiere Pro.

[5] Sugiyono. Metode Penelitian Pendidikan Pendekatan Kuantitatif, Kualitatif. Bandung: Alfabeta(2013).

[6] Trianto. Mendesaian Model Pembelajaran Inovatif, Progesif dan Konstektual. Surabaya: Prenadamedia. . (2014).

[7] Eko, P. W. Evaluasi Program Pembelajaran. Yogyakarta: Pustaka Pelajar. (2009).

[8] Ating, S., \& Sambas, A. M. Statistika Dalam Penelitian . Bandung: Pustaka Setia (2006) 